\title{
Group-occurring landslides and debris flows caused by the continuous heavy rainfall in June 2019 in Mibei village, Longchuan County, Guangdong Province, China
}

\section{Huilin Bai}

Chengdu University of Technology

wenkai feng ( $\square$ fengwenkai@cdut.cn )

Chengdu University of Technology

\section{Xiaoyu Yi}

Chengdu University of Technology

\section{Hongyu Fang}

Chengdu University of Technology

\section{Yiying Wu}

Chengdu University of Technology

\section{Pengcheng Deng}

Chengdu University of Technology

Hongchuan Dai

Chengdu University of Technology

Rui Hu

Chengdu University of Technology

\section{Research Article}

Keywords: group-occurring landslide, debris flow, continuous heavy rainfall, slope structure, engineering excavation

Posted Date: February 12th, 2021

DOl: https://doi.org/10.21203/rs.3.rs-161293/v1

License: (1) This work is licensed under a Creative Commons Attribution 4.0 International License. Read Full License 


\section{Abstract}

From June 10th to 13th, 2019, a continuous heavy rainfall occurred in Longchuan County, Guangdong Province, causing many landslide hazards. Among Longchuan County districts, Mibei village is one of the hardest-hit areas and suffered severe losses. In this paper, field investigation, remote sensing image interpretation , and UAV aerial photography were used to investigate and analyze hazard characteristics. Combined with rainfall monitoring data, laboratory and field tests data, and existing research results, the characteristics and failure mechanism of group-occurring landslides in Mibei village were studied. Because of the continuous heavy rainfall, 327 landslides occurred in the study area, mainly distributed in the north of the Mibei river and along the X158 road. The terrain slope of landslide hazards ranged from $35^{\circ}$ to $45^{\circ}$, and the slope structure can be divided into two types. Granite residual soil was the main part of landslide mass, and sliding surface developed along with the interface between bedrock and covering layer. The continuous heavy rainfall from June 10th to 13th was the main triggering factor of the disaster. The total precipitation was $281.3 \mathrm{~mm}$, and the rainfall on June 10 th was $153.5 \mathrm{~mm}$. The rain led to the continuous increase of volume water content in granite residual soil and completely weathered granite. The shear strength and parameters of the two materials changed differently, and slope stability continued to decrease, and then landslides occurred under terrain conditions and engineering excavation space. Untimely support and unreasonable support measures for the excavation slope exacerbated the disaster. The development degree of debris flows in the study area was very low, and debris flows were shown as the secondary disaster of landslides. The branch gully terrain is the key to transforming the landslide into the debris flow, and a large amount of loose deposits in the main gully will become the potential source of debris flow in the future.

\section{Introduction}

The southeast coastal area of China is located in the subtropical monsoon climate zone, with frequent typhoons and rainstorms. The average annual rainfall ranges from 1300 to $2500 \mathrm{~mm}$. The landslide and debris flow caused by rain are the most common types of geological hazard in this area, and show the characteristics of the small scale of individual hazard point, a large number of groups, and wide distribution range (Chen et al. 2006; Fan et al. 2020; Liu et al. 2020; Yang et al. 2020). The results show that rainfall is the direct triggering factor of this kind of landslide and debris flow. Rain is mainly reflected in rainfall intensity and rainfall duration (Li et al. 2019; Marin 2020; Zhang et al. 2019), and terrain topography, geotechnical property, slope structure, and other factors affect the development characteristics and spatial distribution of hazards(Bhardwaj et al. 2019; Huang et al. 2019; Netto et al. 2013; Wei et al. 2020,2019). Under favorable topographical conditions, landslides caused by rain become the source of debris flow, and the disaster chain of landslide and debris flow is formed, resulting in more significant loss of life and property (Yang et al. 2020; Liu et al. 2020; Fang et al. 2016).

From June 10th to 13th, 2019, there was continuous heavy rainfall for four days in Longchuan County, Guangdong Province, with accumulated rainfall of more than $260 \mathrm{~mm}$. A large number of shallow landslides were triggered in the whole county. Landslide mass mainly developed in granite residual soil 
layer, and a small part of landslides in the gully turned into debris flow. The direct economic loss of the whole county reached 1.545 billion yuan. In this round of heavy rainfall, Longchuan County appeared several severe disaster areas, of which Mibei village is one of the most typical areas. According to local villagers, landslide hazards mainly occurred from 20:00 on June 12th to 04:00 on June 13th (UTC +8), and then there were sporadic landslides. After the rain stopped, the whole Mibei village and its surrounding areas were densely developed with small shallow landslides with $7.2 \mathrm{~km}$ road damaged, $3.2 \mathrm{~km}^{2}$ farmland buried, four houses directly damaged, and more than 50 houses affected by the disaster. The direct economic loss was as high as 120 million yuan. Due to the early release of the disaster's meteorological warning, the local Government transferred 377 residents in time, causing no casualties; the study area's essential characteristics are shown in Fig.1.

After the disaster, the technical team of the Nonferrous Mine Geological Disaster Prevention Center of Guangdong Province rushed to the study area to guide the emergency rescue work. In this process, the hazard background and characteristics of Mibei village were preliminarily mastered. After completing the emergency rescue work, some researchers entirely collected the geological data, optical satellite remote sensing images, rainfall monitoring data, treatment engineering survey reports, and other data of the study area. Then, the research group went to the site to carry out the detailed field investigation again to find out the distribution characteristics of the group-occurring landslides and triggering factors, and complete laboratory and field tests of rock and soil mass. Based on a series of previous work, this paper analyzes the development characteristics and initiation mechanism of group-occurring landslides in Mibei village. It discusses the effect of the landslide-debris flow disaster chain and the influence of engineering activities on the study area.

\section{Data And Methods}

The methods used in this paper mainly include data collection, UAV aerial photography, field investigation, and laboratory and field tests. The data obtained have optical satellite remote sensing images, rainfall monitoring data, UAV orthophoto images, and physical and mechanical parameters of rock and soil mass. A mass of data provides sufficient data support for accurately grasping the development and distribution characteristics of hazards in the study area and initiation mechanism analysis. The details of various information are as follows:

(1) Rainfall monitoring data

The rainfall monitoring data are from the National Meteorological Science Data Center and Longchuan County Meteorological Bureau of Guangdong Province. They include the monthly rainfall data of Longchuan County from 1998 to 2018, daily rainfall data of Beiling meteorological station from May to July of 2019, and hourly rainfall data from June 9 th to 13 th, 2019. The data provide great help to master the study area's meteorological environment and support the correlation analysis of rainfall and hazards in Mibei village. 
(2) Interpretation of optical satellite remote sensing images and UAV orthophoto images

The optical satellite remote sensing images are derived from Google Earth and geological cloud platform


carried out geometric correction by using ALOS $12.5 \mathrm{~m}$ digital elevation model (DEM) data. The optical satellite remote sensing image resolution is very high, with a panchromatic band of $0.5 \mathrm{~m}$ and a multispectral band of $2 \mathrm{~m}$. A digital orthophoto map (DOM) with $0.1 \mathrm{~m}$ accuracy has been obtained through the UAV orthophoto images.

Through the comparison and visual interpretation of optical satellite remote sensing images and UAV orthophoto images, the disaster database of Mibei village is established. Based on spectral information and DEM data, the relationship between slope aspect, terrain slope, elevation, section shape, landslide scar area, and landslide scar area percentage (LSAP) is studied.

(3) Field interview and investigation

After the emergency rescue work, the residents and government managers were interviewed, and all relevant news released by the media were collected to understand the disaster occurrence and the history of landslides and debris flows in the region. Through field investigation, the characteristics of landslides, debris flows, and slope structure in Mibei village have been investigated in detail, and the development and distribution characteristics of landslides and debris flows were fully mastered. The geological background of the disaster was identified.

(4) Laboratory and field tests

The research group selected suitable points to take granite residual soil samples and completely weathered granite samples for the screening test, dry density test, moisture content test, and volume water content test under natural and saturated conditions after completing the field investigation. Various tests obtained the gradation structure and physical and mechanical parameters of granite residual soil and completely weathered granite. Simultaneously, permeability tests were conducted at sampling points to test the saturated permeability coefficient of granite residual soil and completely weathered granite. The data provide significant evidence for the initiation mechanism analysis of slope instability induced by rainfall.

\section{Geological Setting}

The study area is located in the northeast of Guangdong Province and the north of Longchuan County, belonging to the low mountain and hilly terrain. The overall terrain is high in the north and south and low in the middle. The study area's highest altitude is $609 \mathrm{~m}$, and the lowest altitude is $183 \mathrm{~m}$ at the outlet of the Mibei river. The relative height difference is $426 \mathrm{~m}$. Low mountains dominate the northern part of the study area, and the terrain slope is $35^{\circ} \sim 45^{\circ}$. The mountains are steep, and the peaks are sharp and conical. The middle part is the valley with heavy terrain cutting, and its cross-section is mostly V-shaped. 
The southern part is dominated by hilly terrain, and the overall terrain forms a pattern of alternating distribution of low mountains, hills, and valleys. The area of low mountains and hills is relatively large. Simultaneously, the geological structure of the study area is simple, and faults are not found. The seismic intensity is VI degree, and the seismic acceleration is $0.05 \mathrm{~g}$. The characteristic period of the seismic response spectrum is $0.35 \mathrm{~s}$. The geographical location and regional geological environment characteristics of the study area are shown in Fig.2, and the pre-disaster topographic satellite image of the study area is shown in Fig.3.

The bedrock in the study area is Paleozoic granite $\left(p_{\mathrm{z} 1}\right)$, and the quaternary strata are mainly granite residual soil $\left(Q_{4}{ }^{e l}\right)$. The covering layer's thickness varies greatly, ranging from 1.0 to $5.0 \mathrm{~m}$, and there is about 20-30 cm arable soil layer on the surface. Mibei river is the only river in the study area, belonging to the second tributary of the Dongjiang River. Mibei River is about $5 \sim 8 \mathrm{~m}$ wide and $4.1 \mathrm{~km}$ long, with a large flow in the rainy season (March to September) and a small flow in the dry season. Groundwater includes pore water of loose accumulation layer and fissure water of bedrock, with s buried depth of $6.0 \sim 10.0 \mathrm{~m}$, which is mainly supplied by rainfall and finally discharged into Mibei river. It is significantly affected by seasons and the water level changes with seasons.

\section{Characteristics Of Landslides}

\subsection{Spatial distribution of landslides}

The study area is $14.76 \mathrm{~km}^{2}$, and 327 landslides are interpreted by post-disaster high-resolution optical satellite remote sensing images (Fig.4). The total area of landslide scar is $75.25 \times 10^{4} \mathrm{~m}^{2}$, accounting for $5.1 \%$ of the study area. Fig. $4 \mathrm{~b}$ shows that the landslides are mainly distributed in the north of the Mibei river and along the X158 road. Among them, 86 landslides (accounts for $26.3 \%$ ) are adjacent to roads and houses, causing traffic interruption and house damage, which are the leading cause of economic losses. According to the statistical analysis of the landslide scar area, the landslide scar area percentages of less than $5000 m^{2}$ and $10000 m^{2}$ were $87.46 \%(n=286)$ and $96.94 \%(n=317)$, respectively. There are 10 landslides with an area of more than $10000 \mathrm{~m}^{2}$, which are distributed along the X158 road $(n=4)$ and in the valley $(n=6)$.

Fig. 5 shows the relationships between slope aspect, terrain slope, elevation, section shape, landslide scar area, and landslide scar area percentage (LSAP), respectively. Generally, the terrain will affect the distribution of light, airflow, and rainfall in high mountain and canyon areas (Sun et al. 2015; Wang et al. 2018), and there is a particular relationship between landslides caused by rainfall and slope aspect(Jin et al. 2019). The study area belongs to the low mountain and hilly terrain, and the uneven distribution characteristics of rainfall caused by terrain are not significant. Therefore, there is no apparent rule between the slope aspect and landslides in Fig.5a, which is relatively discrete. According to the ALOSDEM data analysis, the terrain slope of landslides is $35^{\circ} \sim 45^{\circ}$ (Fig.5b), and the section shape is the mainly linear type (accounts for 53.62\%), followed by concave type, as shown in Fig.5c. Fig.5d shows that the 
landslides primarily occurred in the elevation range of $300 \sim 400 \mathrm{~m}$. The low-altitude areas $(<300 \mathrm{~m})$ are mostly gully areas with gentle terrain and undeveloped landslides, and the terrain slope of the highaltitude areas $(>400 \mathrm{~m})$ is generally higher than $50^{\circ}$, and rainfall infiltration is less than surface runoff. Therefore, there are few landslides in high-altitude areas. Besides, the vegetation coverage rate in the study area is higher than $90 \%$, mainly arbor and bamboo, and almost all the landslides occurred in the vegetation-covered area. It can be seen that vegetation does not play an essential role in maintaining slope stability under such a geological environment.

\subsection{Landslide scale and slope structure}

Through field investigation and survey of typical landslides, it is easy to determine left and right boundaries and rear edges of landslides. Because the main sliding mass has scraping and accumulation characteristics in the movement process, it is difficult to determine the shear outlet of the front edge. The height difference between the rear edge of the landslide and the front edge of accumulation is 10 20m, and some small-scale landslides are only $3 \sim 5 \mathrm{~m}$. The survey results show that the sliding surface depth of many landslides is about 1.5 3m. Combined with the landslide scar area interpreted by satellite remote sensing images, the landslide mass volume is generally between $10 \sim 40000 \mathrm{~m}^{3}$. There are few landslides greater than $50000 \mathrm{~m}^{3}$, and the landslides of more than $100000 \mathrm{~m}^{3}$ do not occur. Therefore, the landslides in the study area are group-occurring and small-scale. The plane shape of landslides is mainly strip-shaped, and the length of the landslide scar is 2-3 times its width. Some of the landslides distributed in the gully source are fan-shaped, and the landslide mass converges to the channel.

There are two types of sliding bed exposed after the occurrence of a large number of landslides, i.e., completely weathered granite and moderately-strong weathered granite. Combined with the characteristics of the slope structure near the landslide area, the study area's slope structure can be summarized into two types. The first kind of slope structure is composed of moderately-strong weathered granite and granite residual soil with a thickness of $1 \sim 2 \mathrm{~m}$. The sliding surface mainly develops along with the interface between bedrock and covering layer for the landslides under this kind of slope structure. The material composition of landslide mass is primarily composed of fine-grained components, with a small amount of gravel carried away from the moderately-strong weathered granite. The diameter of gravel is $5 \sim 20 \mathrm{~cm}$. After the landslide, the bedrock (moderately-strong weathered granite) was exposed in the middle and front edge of the slope; (Fig.6a, c). The second type of slope structure is composed of moderately-strong weathered granite, completely weathered granite, and granite residual soil. The thickness of granite residual soil is $1.5 \sim 3 \mathrm{~m}$, and the typical thickness of completely weathered granite is $3 \sim 6 \mathrm{~m}$, but the thickness of partial completely weathered granite can reach more than $12 \mathrm{~m}$. There is no outcrop of moderately-strong weathered bedrock in the slope area. Under this kind of slope structure, the sliding surface develops along with the interface between granite residual soil and completely weathered granite, and locally cuts into completely weathered layer. The landslide mass is mainly composed of finegrained components with a small amount of breccia with particle size less than $2 \mathrm{~cm}$ (Fig.6b, d). 


\subsection{Accumulation characteristics of landslides}

There are three types of landslide accumulation in the study area, which are closely related to the location and terrain of the landslide area.

区Long-distance accumulation (Fig.7a)

The landslides with this accumulation form are generally located in the gully source. Under the gravitational potential energy provided by the gully source slope, a large amount of loose landslide mass entered the gully, and then the second stage of the movement would be carried out under the action of the potential energy of the gully. The potential energy provided by the gully is less than that of the gully source slope, so the movement distance of landslide mass was mainly completed in the first stage and completed rapidly. In the second stage, the landslide mass continued to move at a relatively low rate. For a small number of branch ditches with longitudinal gradient higher than $300 \%$, the landslides at the gully source may continue to move to the gully intersection or even to the gully mouth under the gravitational potential energy provided by the slope and the gully, and the maximum movement distance can reach more than $100 \mathrm{~m}$.

『Short-distance accumulation (Fig.7b)

This kind of landslide is distributed on the slopes on both sides of the Mibei river and near the X158 road. The foot of the slope has open and gentle terrain. When the landslide mass moved to the foot of the slope, the sliding rate of landslide mass reduced significantly. Because the open and gentle terrain has no space constraint and no continuous potential energy effect, the landslide mass moved to multiple directions and gradually stopped when it encountered obstacles such as houses and retaining walls. In this process, the houses which play a role of blocking will be damaged in varying degrees. The movement path of this type of landslide is a broken line, and its movement distance is considerably shortened compared with the first type, which is generally $10 \sim 20 \mathrm{~m}$.

\Accumulation of slope toe (Fig.7c)

The landslides are mainly distributed on both sides of the V-type gully. After the landslide mass lost its stability, it strook the slope on the opposite bank through a straight path and then stopped. Loose accumulation of landslides blocked the gully channel. However, since the landslide movement path is nearly vertical to the gully flow direction, the potential energy provided by the gully cannot be converted into the kinetic energy of the continuous landslide. The gully channel is blocked by landslide mass, and the increasing flow with rainfall will continue to gather. Because the scale of landslides in the study area is small, it is difficult to form a barrier dam. When the catchment reaches a certain reserve, the flow will rush out a channel in the loose accumulation, and the collected water will be released quickly, and then it will be transformed into a small-scale, short-term barrier burst debris flow.

\section{Initiation Mechanism Of Landslides}




\subsection{Rainfall distribution}

Fig.8 shows the characteristics of monthly rainfall and average monthly rainfall in Longchuan County, Guangdong Province, from 1998 to 2018. The statistical data shows that the annual rainfall trend of Longchuan County is a bimodal distribution. The rain shows continuous growth from January to June every year and reaches the first rainfall peak in June, with the average monthly rainfall reaching $264.6 \mathrm{~mm}$. Then, the rainfall decreases significantly in July, with the average monthly rainfall less than $170 \mathrm{~mm}$, and the decrease is about $37 \%$ compared to June. In August, the rainfall increases again and reaches the second rainfall peak. The average monthly rainfall reaches $206.5 \mathrm{~mm}$, which is $23.8 \%$ higher than that in July, but the second rainfall peak is less than the first one. After August, the rainfall continues to decrease and finally maintains the same level as that in January and February. The group-occurring landslides in Mibei village of Beiling town occurred in June 2019, which is in the first peak period of rainfall in the region. The disaster also reflects that the heavy rainfall weather causing group-occurring landslides conforms to the area's large climate environment (Wang et al. 2014).

Fig. 9 shows the daily rainfall of the study area from May to July 2019, of which the total rainfall in June 2019 is $524.5 \mathrm{~mm}$, while the monthly accumulated rainfall of $583.8 \mathrm{~mm}$ occurred in 2005 , but it did not cause group-occurring landslides. It can be seen that the monthly accumulated rainfall cannot fully explain the occurrence of group-occurring landslides. There were six days with daily rainfall of more than $40 \mathrm{~mm}$ in these three months, including four days in June, namely $55 \mathrm{~mm}$ on June $1 \mathrm{st}, 153.5 \mathrm{~mm}$ on June 10 th, $72.2 \mathrm{~mm}$ on June 11 th and $111.1 \mathrm{~mm}$ on June $24 \mathrm{th}$. The continuous heavy rainfall from June 10 th to 11 th and the constant rainfall from June 12 th to 13 th $(33 \mathrm{~mm}$ and $22.4 \mathrm{~mm}$, respectively) led to the disaster. Fig.10 shows the hourly rainfall from 20:00 on June 9th to 23:00 on June 13th. Since the early morning of June 10th, there are four rainfall peaks with the hourly rainfall peak of $27 \mathrm{~mm}, 20.7 \mathrm{~mm}$, $36.5 \mathrm{~mm}$, and $48.4 \mathrm{~mm}$, respectively, and the hourly rainfall in other periods is less than $6.1 \mathrm{~mm}$. According to local villagers, most of the landslides and debris flows occurred from 20:00 (UTC +8$)$ on June 12th to 04:00 on June 13th in Mibei village. After the hourly rainfall peak of $48.4 \mathrm{~mm}$ on June 11th, the accumulated rainfall has exceeded $230 \mathrm{~mm}$, which further reflects the control role of extreme rainfall from June 10 th to 11 th in the disaster, and also shows the lag effect between disaster and rainfall.

\subsection{Initiation mechanism analysis}

From the process of the disaster, the continuous heavy rainfall is the direct factor leading to groupoccurring landslides, and the continuous heavy rainfall is the external natural factor. The change of internal geological conditions based on rains (such as slope structure, physical and mechanical properties of rock and soil) is the key to group-occurring landslides.

The physical and mechanical parameters of granite residual soil, completely weathered granite, and strongly weathered granite in the study area are obtained through laboratory and field tests, as shown in Table.1. The field permeability test shows that the permeability coefficient of granite residual soil belongs 
to the order of $10^{-5} \sim 10^{-4} \mathrm{~cm} / \mathrm{s}$, and the permeability coefficient of completely weathered granite belongs to the order of $10^{-4} \sim 10^{-3} \mathrm{~cm} / \mathrm{s}$. The difference of permeability coefficient between them is $1 \sim 2$ orders of magnitude, which leads to the difference in rainfall infiltration and pore water pressure. The gradation structure can explain the contrast in permeability. In Fig.11, the particle mass of less than $2 \mathrm{~mm}$ in the granite eluvium and completely weathered layer accounts for about $96.5 \%$ and $85.6 \%$ of the total mass, respectively. The clay content of less than $0.075 \mathrm{~mm}$ is higher than $8 \%$ in granite residual soil, while that of completely weathered granite is only about $4 \%$. In the particle size range of $0.5 \sim 2 \mathrm{~mm}$, the percentage of granite residual soil is $28 \sim 33 \%$, and the portion of completely weathered granite can reach more than $40 \%$. It can be seen that the sand content in the completely weathered layer is higher than that in granite eluvium, while the clay content is lower than that of granite eluvium. High sand content and low clay content also make the permeability of completely weathered layer stronger than that of granite eluvium, reflecting an absolute correlation between the permeability and particle gradation of completely weathered layer and granite eluvium.

Table.1 Physical and mechanical properties of residual soil and granite

\begin{tabular}{|c|c|c|c|c|c|c|c|}
\hline $\begin{array}{c}\text { Weathering } \\
\text { Grade }\end{array}$ & $\begin{array}{c}\text { dry } \\
\text { density } \rho_{\mathrm{d}} \\
\left(\mathrm{g} / \mathrm{cm}^{3}\right)\end{array}$ & $\begin{array}{c}\text { saturated water } \\
\text { content } w_{\mathrm{S}}(\%)\end{array}$ & $\begin{array}{c}\text { natural } \\
\mathrm{condition} \\
\mathrm{C}(\mathrm{kPa})\end{array}$ & $\begin{array}{c}\text { natural } \\
\mathrm{condition} \\
\varphi\left({ }^{\circ}\right)\end{array}$ & $\begin{array}{c}\text { saturated } \\
\text { condition } \\
\mathrm{C}(\mathrm{kPa})\end{array}$ & $\begin{array}{c}\text { saturated } \\
\mathrm{condition} \\
\varphi\left({ }^{\circ}\right)\end{array}$ & $\begin{array}{c}\text { permeability } \\
\mathrm{coefficient} \\
\mathrm{k}_{\mathrm{S}}(\mathrm{cm} / \mathrm{s})\end{array}$ \\
\hline residual soil & 1.48 & 32.4 & 31.66 & 28.53 & 19.72 & 22.33 & $\begin{array}{c}3.6 \times 10^{-5} \sim \\
2.8 \times 10^{-4}\end{array}$ \\
\hline $\begin{array}{c}\text { completely } \\
\text { weathered } \\
\text { granite }\end{array}$ & 1.42 & 35.8 & 26.54 & 32.71 & 21.84 & 28.69 & $\begin{array}{c}8.3 \times 10^{-4} \sim \\
1.9 \times 10^{-3}\end{array}$ \\
\hline $\begin{array}{c}\text { strongly } \\
\text { weathered } \\
\text { granite }\end{array}$ & 1.82 & - & 33.28 & 41.37 & - & - & - \\
\hline
\end{tabular}

Due to the difference of physical properties between granite residual soil and completely weathered granite, the mechanical properties are different. It can be seen from Table.1 that the cohesion $(c / k P a)$ of granite residual soil under natural condition is higher than that of completely weathered granite, but the internal friction angle $\left(\varphi /{ }^{\circ}\right)$ is lower. Moreover, the strength parameters of granite residual soil under saturated condition are lower than that of completely weathered granite. The cohesion and internal friction angle of granite residual soil decreased by $37.71 \%$ and $21.73 \%$, respectively, under saturated condition, while the cohesion and internal friction angle of completely weathered granite decreased by $17.7 \%$ and $12.28 \%$, respectively. The strength attenuation degree of granite residual soil affected by rainfall was much greater than that of completely weathered granite, and the cohesion of the two materials was more affected by rain than that of internal friction angle An et al. 2020). The main minerals of granite residual soil and completely weathered granite are kaolinite, illite, and quartz(Wang et al. 2020), and the chemical properties are relatively stable. The seepage force of pore water in the process of rainfall infiltration promotes the expansion of mineral particles and forms quite a lot of microcracks, which affects the frictional strength of granite residual soil and completely weathered granite. The lubrication and softening effects of pore water on fine particles (especially residual soil) are reflected in the attenuation of cohesive strength(Chen et al. 2015). 
The change of shear strength is finally reflected in the slope stability, and the continuous weakening of rock and soil strength results in the decrease of slope stability. Seepage field is formed along the direction and angle of the interface between bedrock and covering layer inside the slope, and underground water migrates to the toe of the slope. In this process, seepage force and strength attenuation of rock and soil lead to slope stability decline. Due to the difference of permeability between granite eluvium and completely weathered layer, a local saturated area will be formed at the foot of the slope, and the loss of soil shear strength in the resist-slide part leads to the overall instability of the slope. From the previous research results, the frictional strength is more conducive to maintain the stability of the slope, so in the slope composed of granite residual soil and completely weathered granite, the landslide mass mostly slides along the interface between granite eluvium and completely weathered layer. For the slope of granite residual soil and moderately-strong weathered granite, the difference of permeability leads to the formation of retention at the interface of two materials after rainfall infiltration. The seepage movement of pore water along with the interface towards the foot of the slope occurs. With the continuous rainfall, the saturated zone gradually forms at the interface between the bedrock and covering layer, and the scope expands continuously. The sharp decrease of the saturated shear strength of granite residual soil will cause the residual soil in the shallow layer to slide along the interface.

In the study area, the influence of human engineering activities is mainly reflected in the excavation of the slope, and the free face with different heights is formed after excavation. The terrain environment created by this human factor is very conducive to the slope sliding out from the free face. Under the condition of no rainfall, this kind of slope can maintain the overall stability under the shear strength of rock and soil, but in the process of continuous heavy rainfall, the shear strength of rock and soil decreases, and the slope stability decreases continuously. At this time, the free slope formed by manual excavation constitutes the terrain condition of sliding out, which is conducive to the deformation and failure of the slope. This phenomenon is mainly distributed on both sides of the road with intensively excavated slopes, so the group-occurring landslides are more distributed along the X158 road.

It can be seen that the occurrence of group-occurring landslides in the study area involves many factors, among which the continuous heavy rainfall is the direct triggering factor. The structural characteristics of slope and the physical and mechanical properties of rock and soil are the internal conditions of the disaster, and intense human engineering activities can intensify and promote the occurrence of landslides.

\section{Discussions}

\subsection{Characteristics and initiation mechanism of debris flow}

According to the investigation and statistics results, the small landslides account for a large proportion of the disaster caused by continuous heavy rainfall in the study area, and the debris flows are not prominent. There are only four debris flows in the whole study area, and all of them occurred in the branches of gullies. This kind of branch ditch has a short channel, large longitudinal slope, and small 
catchment area. The substance source of debris flow in the branch ditch comes from the landslide at the gully source. Under the channel terrain condition, collected surface water makes the loose landslide mass saturated and presents a flow state. It moves under the gravitational potential energy provided by the gully terrain, scraping the early accumulation along the gully and damaging the vegetation on both sides of the slope. Therefore, debris flow in the study area is more like the secondary disaster caused by a landslide, as shown in Fig.12. The post-disaster calculation results show that the mass of solid material washed out by the debris flow gully is about $0.04 \sim 0.3 \times 10^{4} \mathrm{~m}^{3}$, and the fluid density is between $1.5 \sim 1.53 \mathrm{t} / \mathrm{m}^{3}$. From the start of debris flow to the stable accumulation in the gully mouth, the flow velocity increases first and then decreases, and presents a stage change process. The maximum flow velocity is $3.5 \mathrm{~m} / \mathrm{s}$, and the minimum flow velocity is less than $1.0 \mathrm{~m} / \mathrm{s}$. The change and fluctuation of gully terrain are the main factors affecting the flow velocity change.

The formation of debris flow is closely related to rainfall, terrain topography, slope structure, and physical and mechanical properties of rock and soil. The substance source of this kind of small debris flows is distributed in gully source slope. Rainfall is the direct triggering factor of slope instability. The mechanism of slope instability caused by rain will not be described here. After the slope is unstable, the landslide mass will have a movement distance under the gravitational potential energy. However, due to the pore water content not reaching saturation at this stage, the loose landslide mass is scattered and accumulated, and the permeability is much improved (Crosta and Frattini 2008). Under the effect of continuous heavy rainfall, the pore water content of loose landslide mass increases rapidly in a short period, resulting in the accumulation showing a flow state. At this time, under the gravitational potential energy of the gully, the loose landslide mass is transformed into the debris flow, and the velocity increases and reaches the peak value. Then, the terrain gradually slows down near the gully mouth, and the flow velocity decreases. The debris flow finally stops and accumulates. In this process, the gravitational potential energy provided by the gully is the key to the initiation of debris flow. These small branch ditches have similar topographic characteristics, which lead to debris flow. However, the main gully generally reaches $3 \sim 4 \mathrm{~km}$. In addition to the larger topographic slope in the source slope area and the longitudinal gradient of the middle gully is less than $110 \%$, it cannot provide continuous potential energy for the initiation and movement of debris flow. For the landslides in the main gully, most of the landslides accumulated in the gullies, and a small part of them moved along the gullies for a short distance, but debris flow hazard did not form this time. This situation leaves hidden danger for the next heavy rainfall, becoming the potential substance source of debris flow in the next stage. However, due to the terrain condition, the flow velocity is relatively low after the start-up, and it has less destructive power, but a large amount of debris flow substance cannot be ignored for burying buildings and farmland.

\subsection{Influence of engineering activities}

The survey results show that there are 72 landslides along the X158 road, accounting for $22 \%$ of the total number, showing the characteristics of development along the road. It can be seen that engineering activities play an essential role in the group-occurring landslides. The influence of engineering activities 
on slope stability is mainly reflected in two aspects: one is that the slopes are not supported in time after excavation; the other is that the support measures for excavation slope are not effective.

\section{$\nabla$ No timely support measures}

The X158 road in the study area passes through the low mountain and hilly, and the slope is excavated because of the terrain, to form the excavation slope with the height of $2 \sim 15 \mathrm{~m}$, and the terrain slope is generally $40^{\circ} \sim 50^{\circ}$ in a straight line. Due to the low frequency of local geological hazards, most of these excavated slopes are not timely and effectively supported. In the excavated surface, the boundary between granite residual soil and completely weathered granite is clear, providing good free space conditions for sliding out along the interface of granite eluvium and the completely weathered layer in Fig.13a. The group-occurring landslide hazards in the study area also provide a warning for the later engineering construction. The rainfall in the study area has the peak characteristics over the years, which does not rule out the recurrence of continuous heavy rainfall again. The future engineering activities should fully consider the slope structure characteristics, evaluate the stability of the excavation slope, and timely and effective support should be carried out for the excavation slope with the risk of instability to reduce the landslide hazards caused by rainfall in the future.

\section{\Unreasonable supporting measures}

After the disaster occurred in June 2019, the local Government repaired the X158 road in time to keep the lifeline unobstructed. Retaining walls with a height of about $1.3 \mathrm{~m}$ were built for the crucial slopes along the road, and vegetation greening was adopted for the slope surface. After the rainy season of 2020 , the front edge of the retaining slope along the X158 road appears new deformation signs, and even locally sliding failure occurs, as shown in Fig.13b. Through investigation and analysis, it is found that the support measures are not reasonable. The excavation slope reveals granite residual soil and completely weathered granite, while the height of the retaining wall is lower than the boundary of granite eluvium and completely weathered layer. The sliding surface of shallow landslide mainly develops along with the interface of granite eluvium and completely weathered layer, so the retaining wall does not play its full role. It is suggested that before adopting retaining walls and other types of supporting measures in later engineering construction, the structural characteristics of the slope should be fully identified, and the corresponding size design should be carried out to avoid similar situations.

\section{Conclusion}

Combined with field investigation and remote sensing image interpretation analysis, this paper studies the spatial distribution and development characteristics of the group-occurring landslides in Mibei village, Longchuan County, Guangdong Province, due to the continuous heavy rainfall from June 10th to 13th, 2019. The rain caused 327 landslides, which were mainly distributed in the north of the Mibei river and along the X158 road and concentrated in $300 \sim 400 \mathrm{~m}$. The landslide terrain slope is mainly between $35^{\circ}$ and $45^{\circ}$, and there are two types of slope structures, involving granite eluvium, a completely weathered layer, a moderately strong weathered layer, and the landslide mass is mainly granite residual soil. There 
are three kinds of accumulation patterns of shallow landslides: long-distance accumulation, shortdistance accumulation, and accumulation of slope toe. The form of movement and accumulation is closely related to terrain and landslide spatial position.

The disaster in Mibei village is caused by various factors, among which continuous heavy rainfall is the direct triggering factor. The terrain, slope structure, rock and soil properties, and engineering activities affect the formation and development of landslides from different angles and in different forms. Continuous rainfall occurred in the study area from June 10th to 13th, 2019, with a total rainfall of $281.3 \mathrm{~mm}$, of which the rainfall on June 10 th was $153.5 \mathrm{~mm}$. The continuous heavy rainfall led to the sharp increase of pore water content of rock and soil mass, and the shear strength and shear strength parameters of different materials changed differently, which leads to the start-up of landslides under the spatial conditions provided by terrain and engineering activities. The occurrence of group-occurring landslide hazard is closely related to road construction. No timely supporting measures and unreasonable supporting measures become the driving force of disaster aggravation.

There are only four debris flows in the study area. The debris flow hazards are secondary disasters of landslides, all of which occurred in the short branch ditch. At present, A large number of loose deposits are distributed in the main gully, leaving hidden dangers for the later heavy rainfall.

\section{Declarations}

Acknowledgments After the disaster, the State Council and the Ministry of Natural Resources issued essential instructions on the emergency rescue work in the stricken area. Governmental departments at all levels of Guangdong Province and Guangdong Volunteer Association actively and quickly rushed to the stricken area to carry out relevant rescue work, which significantly reduced the loss of life and property. In writing the paper, we received the support and help of many departments and individuals, which provided great convenience for developing the research work, and we would like to express our sincere thanks to them. We would like to thank the relevant departments of the Nonferrous Mine Geological Disaster Prevention Center of Guangdong Province for providing geological data and exploration reports, which help us to comprehensively grasp the study area's geological environment conditions. We are grateful to the people's Government, the Meteorological Bureau, Natural Resources Bureau of Longchuan County to provide us with important rainfall data at different stages and help us carry out fieldwork, which has extensively promoted the research work. At the same time, we are here to express our gratitude to all the Mibei village residents for helping us understand the specific situation of the disaster and assist the research group in completing part of the field tests. We wish them a better life as soon as possible. Besides, we would like to thank Google Earth and geological cloud site ( http://geocloud.cgs.gov.cn/ ) for providing remote sensing datum.

Funding This research is financially supported by The National Natural Science Foundation of China (Grant No. 41977252, U2005205), The Team Project of Independent Research of SKLGP (Grant No.

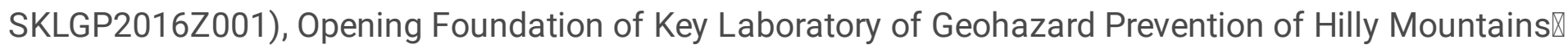


Ministry of Natural Resources(Fujian Key Laboratory Of Geohazard Prevention) (Grant No. FJKLGH2021K006), The Research Project of Nonferrous Mine Geological Disaster Prevention Center of Guangdong Province.

\section{Compliance with ethical standards}

Conflict of interest The authors declare that they have no conflict of interest.

\section{References}

Bhardwaj A, Wasson RJ, Ziegler AD, Chow WTL, Sundriyal YP (2019) Characteristics of rain-induced landslides in the Indian Himalaya: A case study of the Mandakini Catchment during the 2013 flood Geomorphology 330:100-115 doi:10.1016/j.geomorph.2019.01.010

Chen H, Dadson S, Chi Y (2006) Recent rainfall-induced landslides and debris flow in northern Taiwan Geomorphology (Amsterdam, Netherlands) 77:112-125 doi:10.1016/j.geomorph.2006.01.002

Crosta GB, Frattini P (2008) Rainfall-induced landslides and debris flows Hydrol Process 22:473-477 doi:10.1002/hyp.6885

Fan L, Lehmann P, Zheng C, Or D (2020) Rainfall Intensity Temporal Patterns Affect Shallow Landslide Triggering and Hazard Evolution Geophys Res Lett 47 doi:10.1029/2019GL085994

Huang B et al. (2019) Correlation between shear strength and soil physicochemical properties of different weathering profiles of the non-eroded and collapsing gully soils in southern China J Soil Sediment 19:3832-3846 doi:10.1007/s11368-019-02313-7

Li Y, Ma C, Wang Y (2019) Landslides and debris flows caused by an extreme rainstorm on July 212012 in mountains near Beijing, China B Eng Geol Environ 78:1265-1280 doi:10.1007/s10064-017-1187-0

Liu W, Song X, Luo J, Hu L (2020) The processes and mechanisms of collapsing erosion for granite residual soil in southern China J Soil Sediment 20:992-1002 doi:10.1007/s11368-019-02467-4

Liu W, Yang Z, He S (2020) Modeling the landslide-generated debris flow from formation to propagation and run-out by considering the effect of vegetation Landslides doi:10.1007/s10346-020-01478-4

Marin RJ (2020) Physically based and distributed rainfall intensity and duration thresholds for shallow landslides Landslides 17:2907-2917 doi:10.1007/s10346-020-01481-9

Netto ALC et al. (2013) January 2011: The Extreme Landslide Disaster in Brazil.Springer Berlin Heidelberg,Berlin, Heidelberg,pp 377-384. 'doi:'10.1007/978-3-642-31319-6_51 
Wei X, Fan W, Chai X, Cao Y, Nan Y (2020) Field and numerical investigations on triggering mechanism in typical rainfall-induced shallow landslides: a case study in the Ren River catchment, China Nat Hazards 103:2145-2170 doi:10.1007/s11069-020-04075-9

Wei Y, Wu X, Xia J, Miller GA, Cai C, Guo Z, Hassanikhah A (2019) The effect of water content on the shear strength characteristics of granitic soils in South China Soil and Tillage Research 187:50-59 doi:10.1016/j.still.2018.11.013

Yang H, Yang T, Zhang S, Zhao F, Hu K, Jiang Y (2020) Rainfall-induced landslides and debris flows in Mengdong Town, Yunnan Province, China Landslides 17:931-941 doi:10.1007/s10346-019-01336-y

Yang Z, Wang L, Qiao J, Uchimura T, Wang L (2020) Application and verification of a multivariate realtime early warning method for rainfall-induced landslides: implication for evolution of landslidegenerated debris flows Landslides 17:2409-2419 doi:10.1007/s10346-020-01402-w

Zhang K, Wang S, Bao H, Zhao X (2019) Characteristics and influencing factors of rainfall-induced landslide and debris flow hazards in Shaanxi Province, China Nat Hazard Earth Sys 19:93-105 doi:10.5194/nhess-19-93-2019

An R, Kong L, Li C, Luo X (2020) Damage characteristics of mechanics and microstructure of granite residual soil under hot and rainy weather Chinese Journal of Rock Mechanics and Engineering https://doi.org/10.13722/j.cnki.jrme.2020.0073

Chen W, Jian W, Dong Y, Lin X (2015) Influence of weak structural surface on stability of granite residual soil slopes The Chinese Journal of Geological Hazard and Control 26:23-30 doi:10.16031/j.cnki.issn.1003-8035.2015.01.004

Feng W, Hu Y, Xie J, Wang Q, Wu G (2016) Disaster mechanism and stability analysis of shattered bedding slopes triggered by rainfall - a case study of Sanxicun landslide Chinese Journal of Rock Mechanics and Engineering 35:2197-2207 doi:10.13722/j.cnki.jrme.2016.0420

Jian W, Hu H, Luo Y, Tang W (2017) Experimental study on deterioration of granitic residual soil strength in wetting-drying cycles Journal of Engineering Geology 25:592-597 doi:10.13544/j.cnki.jeg.2017.03.003 Jin G, Wang Y, Liu J, Xu J, Shen T (2019) Study on the contribution rate of slope aspects to landslides in Bailong river basin Journal of Northwest Normal University (Natural Science) 55:100-105 doi:10.16783/j.cnki.nwnuz. 2019.05.017

Sun Q, Yu M (2015) Analysis on precipitation variations of characteristics of Minxi zone in the recent 30 years Journal of Fujian Normal University (Natural Science Edition) 31:98-105

Wang L, Miao J, Han F (2018) Overview of impact of topography on precipitation in China over last 10 years Meteorological Science and Technology 46: 64-75 doi:10.19517/j.1671-6345.20170081 
Wang M, Yan J, Li S (2014) Spatial-temporal variation and the tendency of droughts and floods on the southeast coast of China over 54 years Resources Science 36:2307-2315

Wang Z, Zhou Y, Li B, Tan B, Han X (2020) Micro-structure and evolution of relict joints and weathered granite soils in the southeastern Guangxi, China Journal of Earth Sciences and Environment 42:405-415 doi:10.19814/j.jese.2019.10040

\section{Figures}
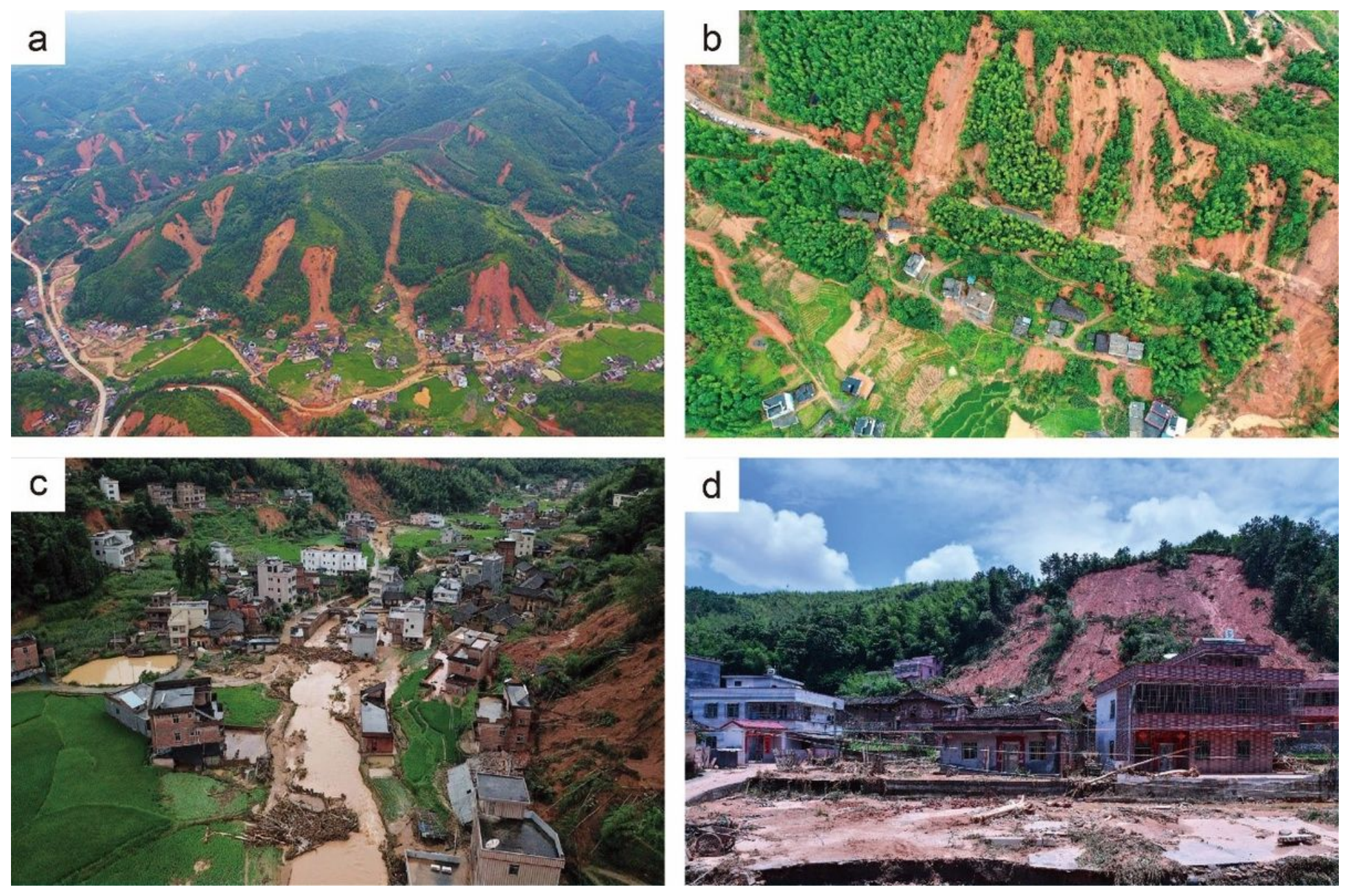

\section{Figure 1}

Post-disaster photos of Mibei Village $\ J u n e ~ 13,2019 \rrbracket$. (a) Aerial view of Mibei village after the disaster (provided by Hua Zhang); (b) The landslide characteristics along X158 road (provided by Xiangtao Zhang); (c) Buried roads, river, farmland (provided by Mingming Tang); (d) The damage of landslide to houses (provided by Wei Xie) 

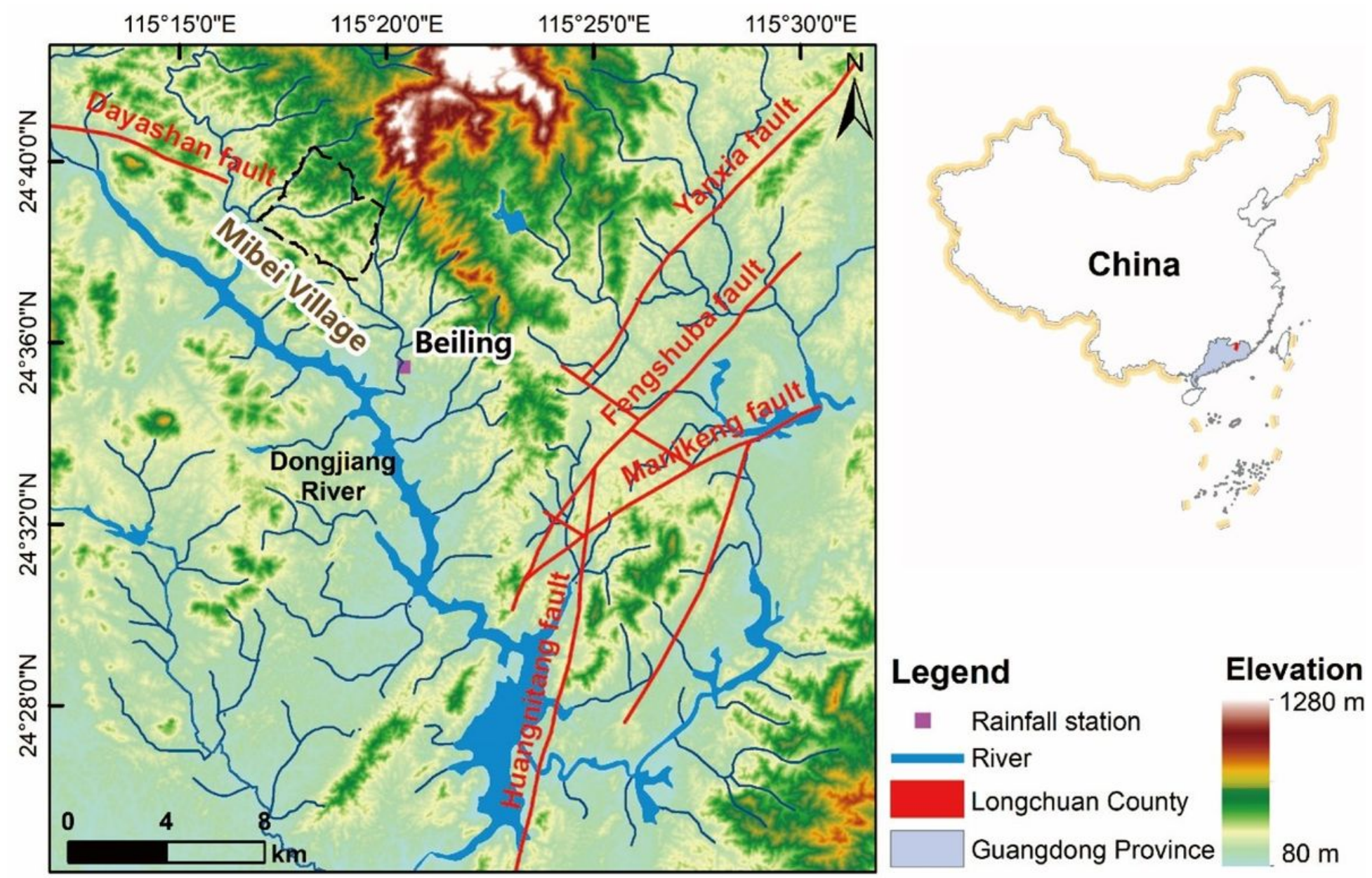

Figure 2

Geographical location and geological environment characteristics of the study area. Note: The designations employed and the presentation of the material on this map do not imply the expression of any opinion whatsoever on the part of Research Square Company concerning the legal status of any country, territory, city or area or of its authorities, or concerning the delimitation of its frontiers or boundaries. This map has been provided by the authors. 


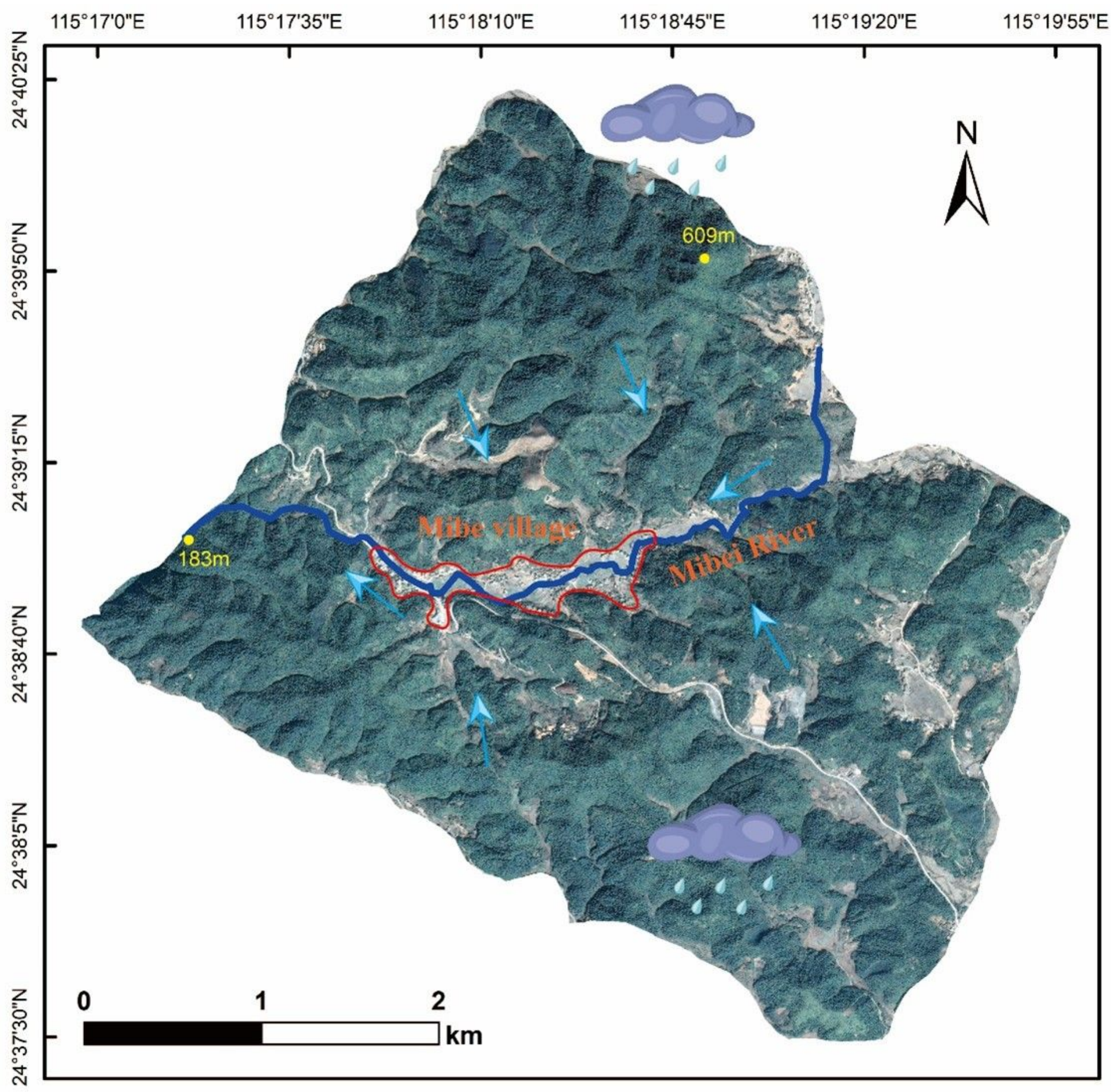

Figure 3

Pre-disaster remote sensing image of the study area $₫$ January 24,2019 , according to Google Earth $\rrbracket$ 

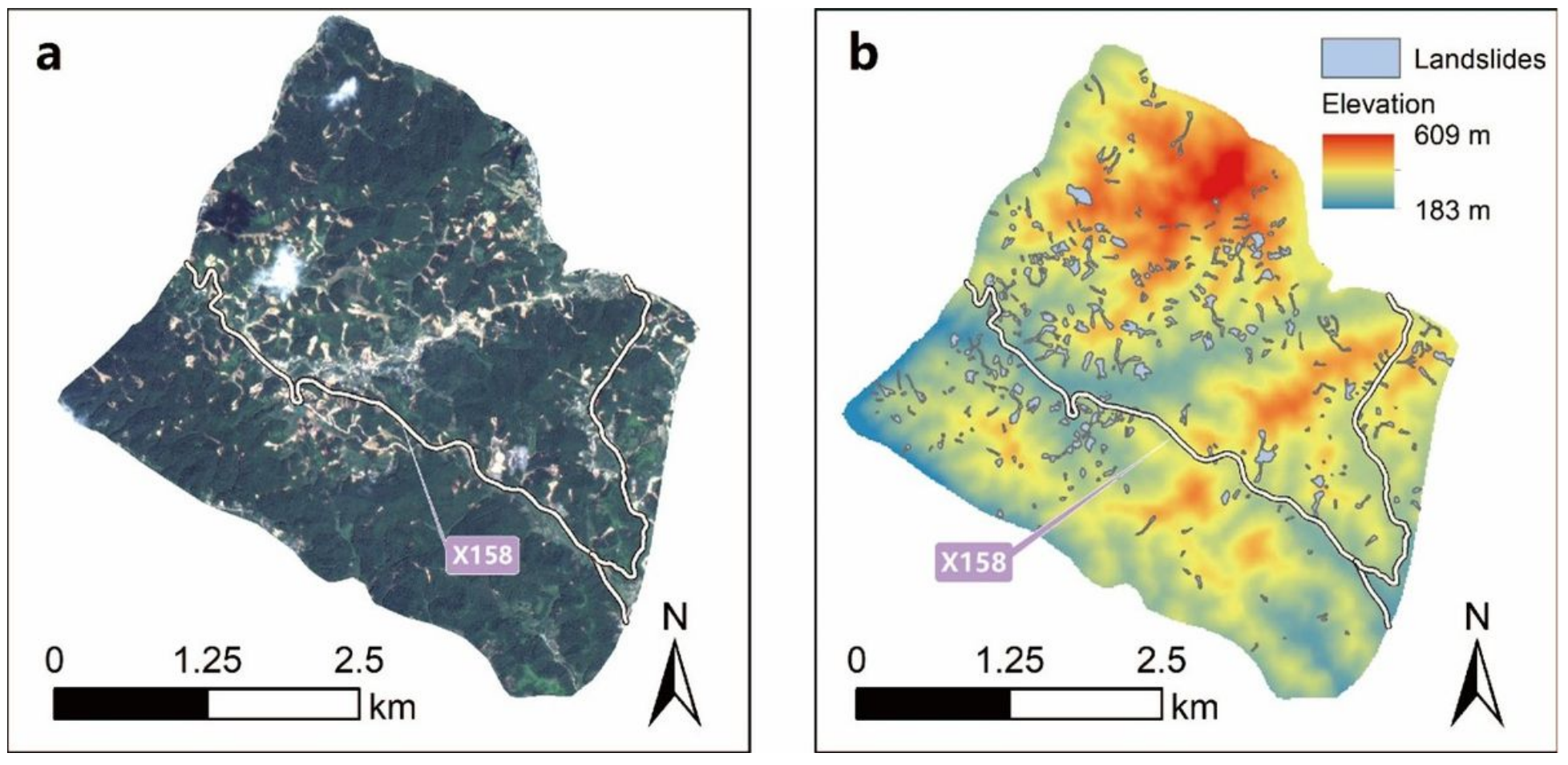

Figure 4

(a) Remote sensing image of the study area taken by Gaofen-1 on August 24th, 2019; (b) Spatial distribution of landslides interpreted by remote sensing image

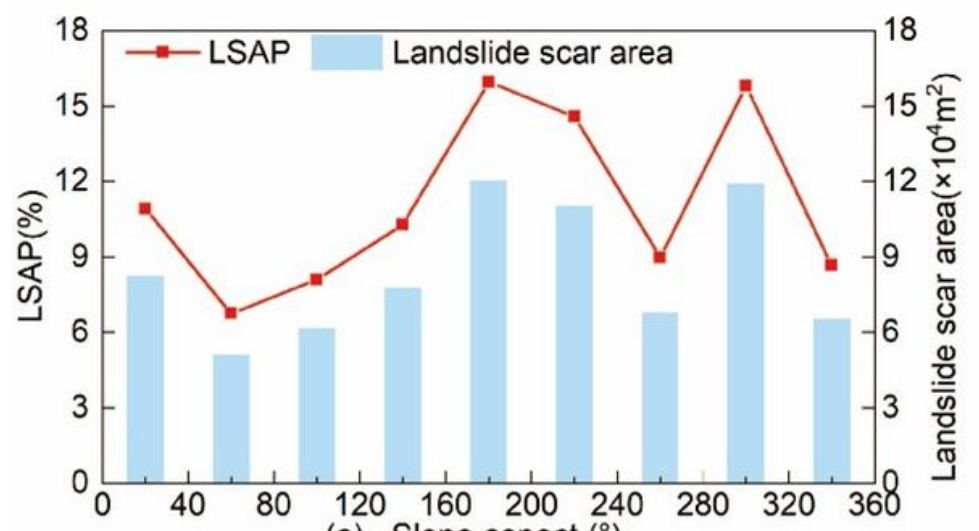

(a) Slope aspect $\left(^{\circ}\right)$

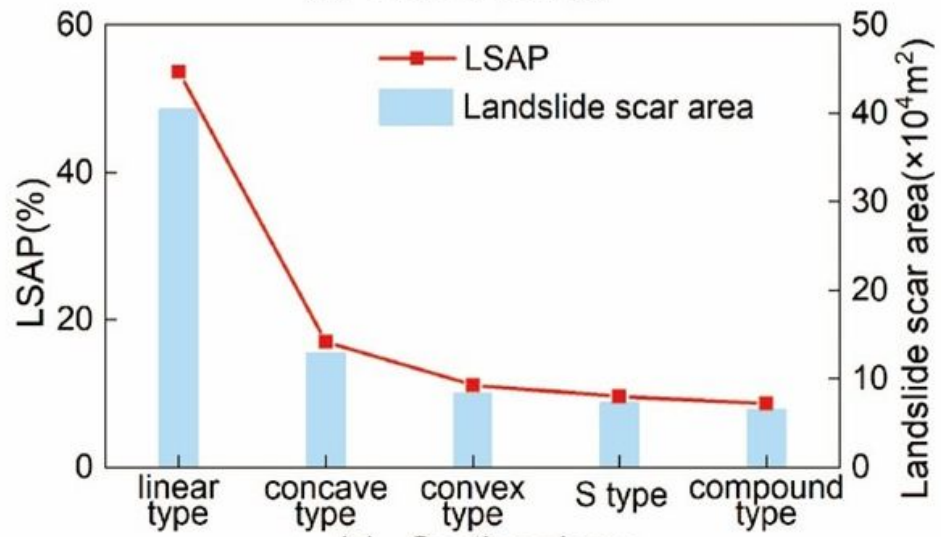

(c) Section shape

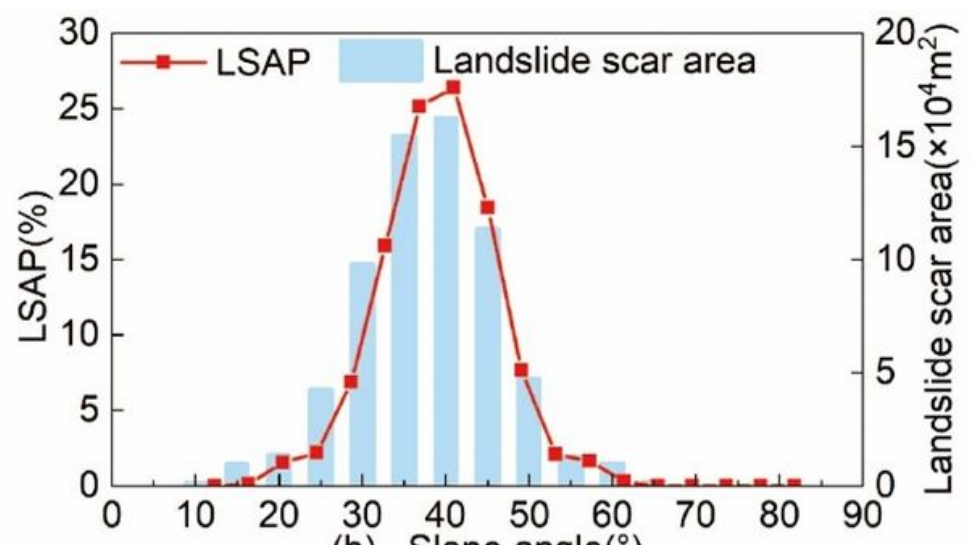

(b) Slope angle $\left({ }^{\circ}\right)$

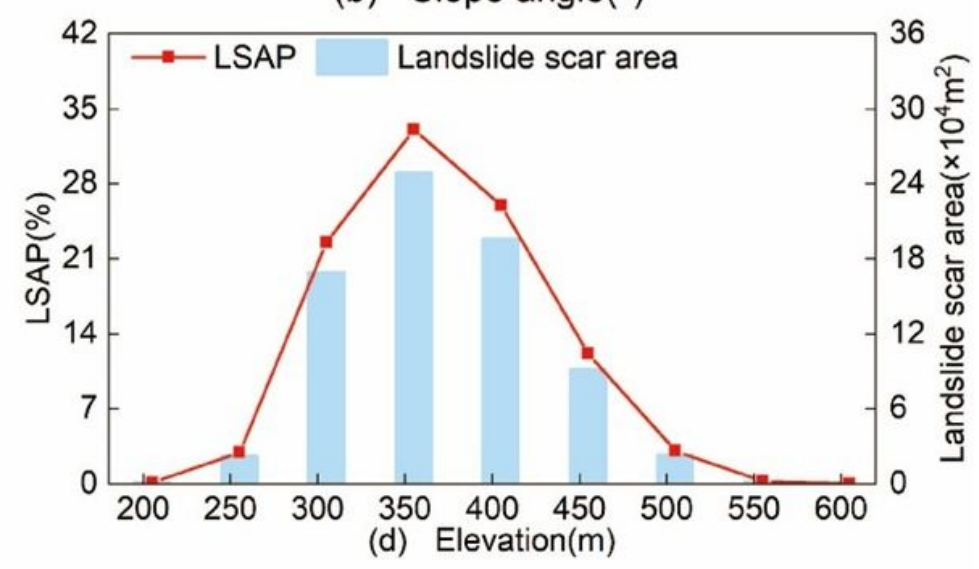

Figure 5 
Relationship between landslide scar area, landslide scar area percentage (LSAP) and slope aspect, slope angle, section shape, elevation. (a)Slope aspect; (b)Slope angle; (c)Section shape; (d)Elevation
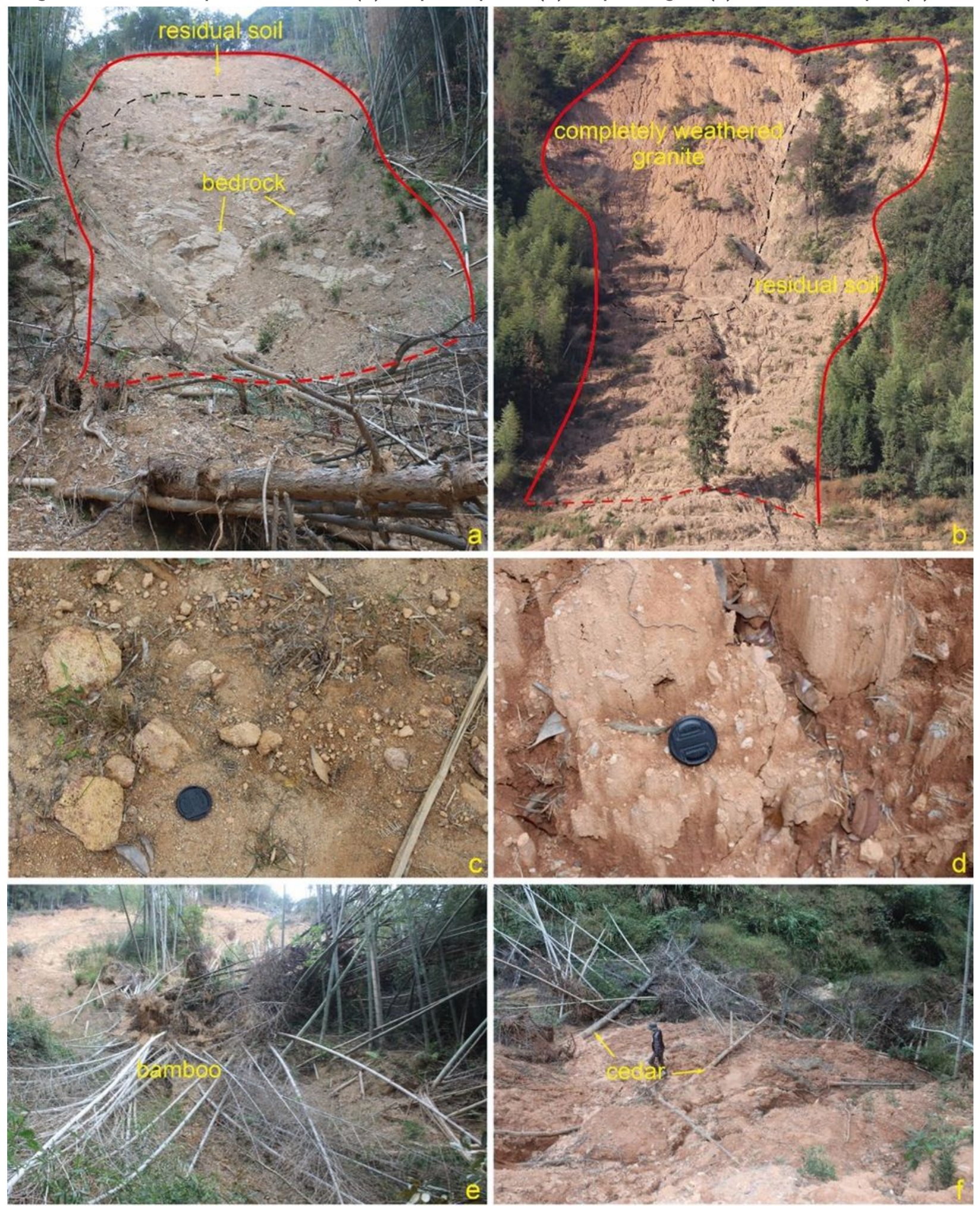

\section{Figure 6}

Structural characteristics and material composition of typical landslides Also, due to the very high growth density of bamboo and cedar in the study area, plant roots and stems mixed with loose landslide accumulation in the process of landslide movement. During the investigation, many plant debris were 
found in the landslide accumulation, with a maximum diameter of $20 \mathrm{~cm}$ and a maximum length of $5 \mathrm{~m}$. Plant debris has an individual impact on the movement and accumulation of landslides, as shown in Fig.6e, $\mathrm{f}$.
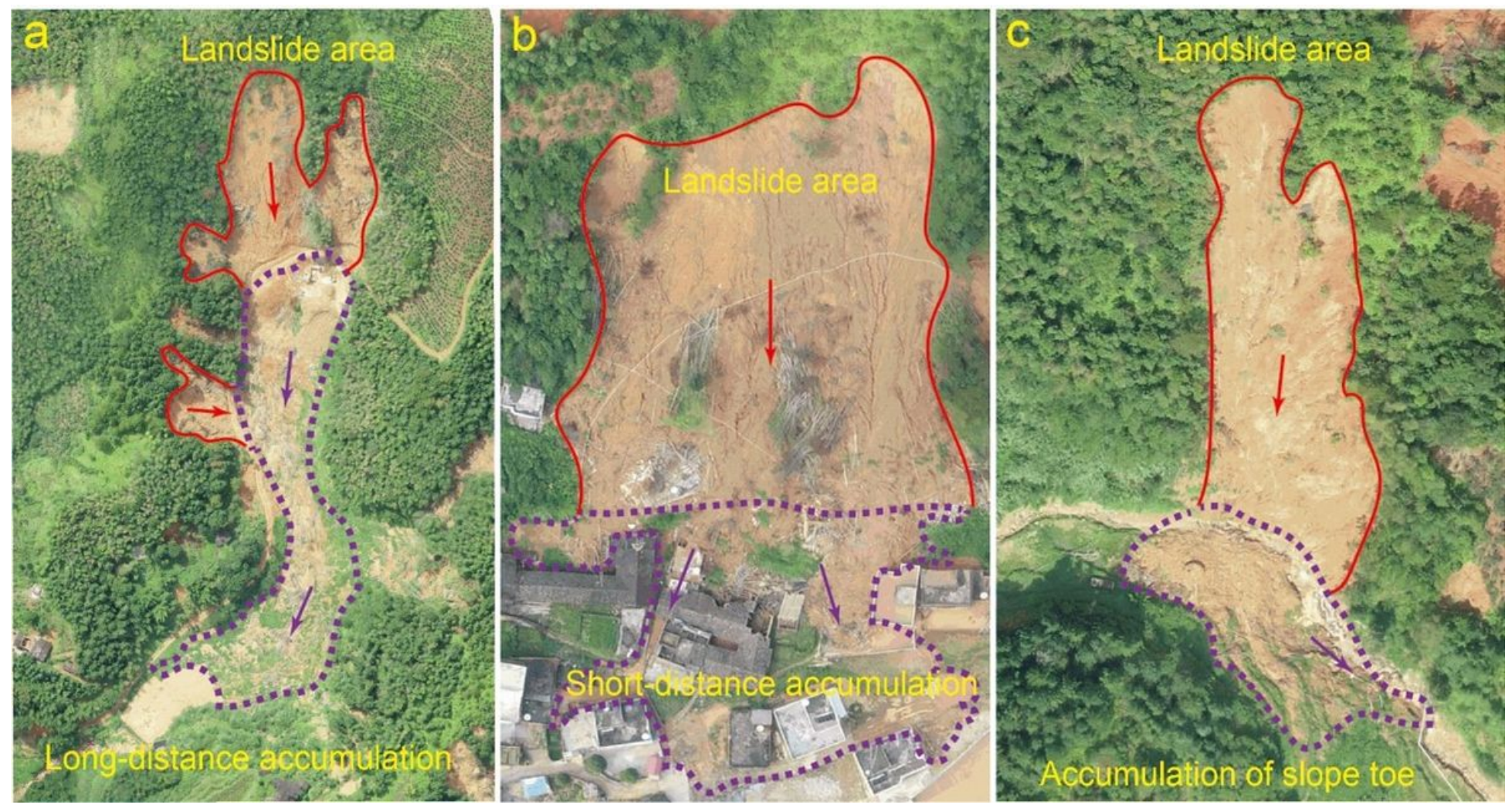

Figure 7

Plane characteristics of landslide accumulation (digital orthophoto map)

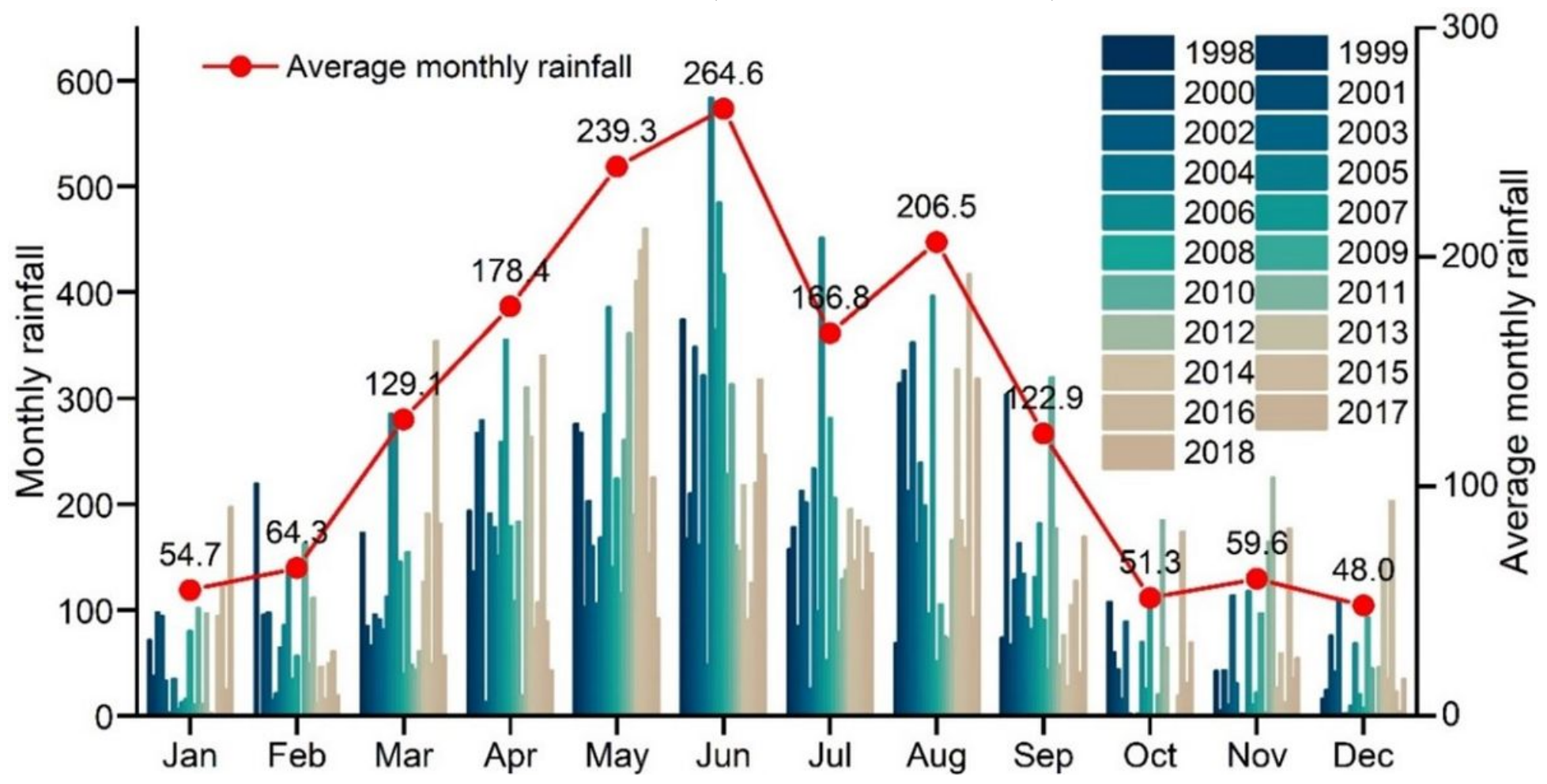


Figure 8

Distribution of monthly rainfall and average monthly rainfall in Longchuan County from 1998 to 2018

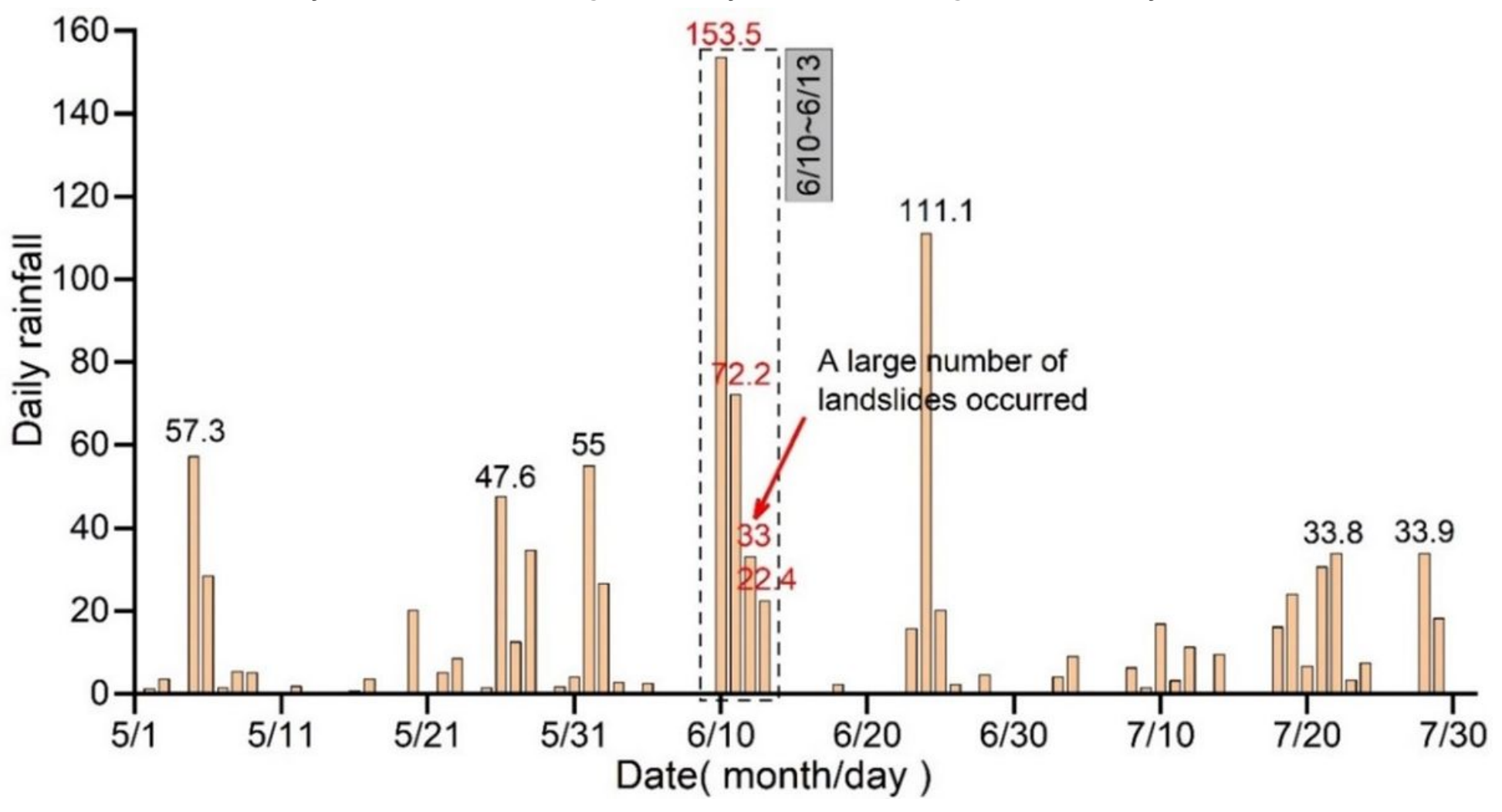

Figure 9

Distribution of daily rainfall in Beiling town, Longchuan County from May to July, 2019

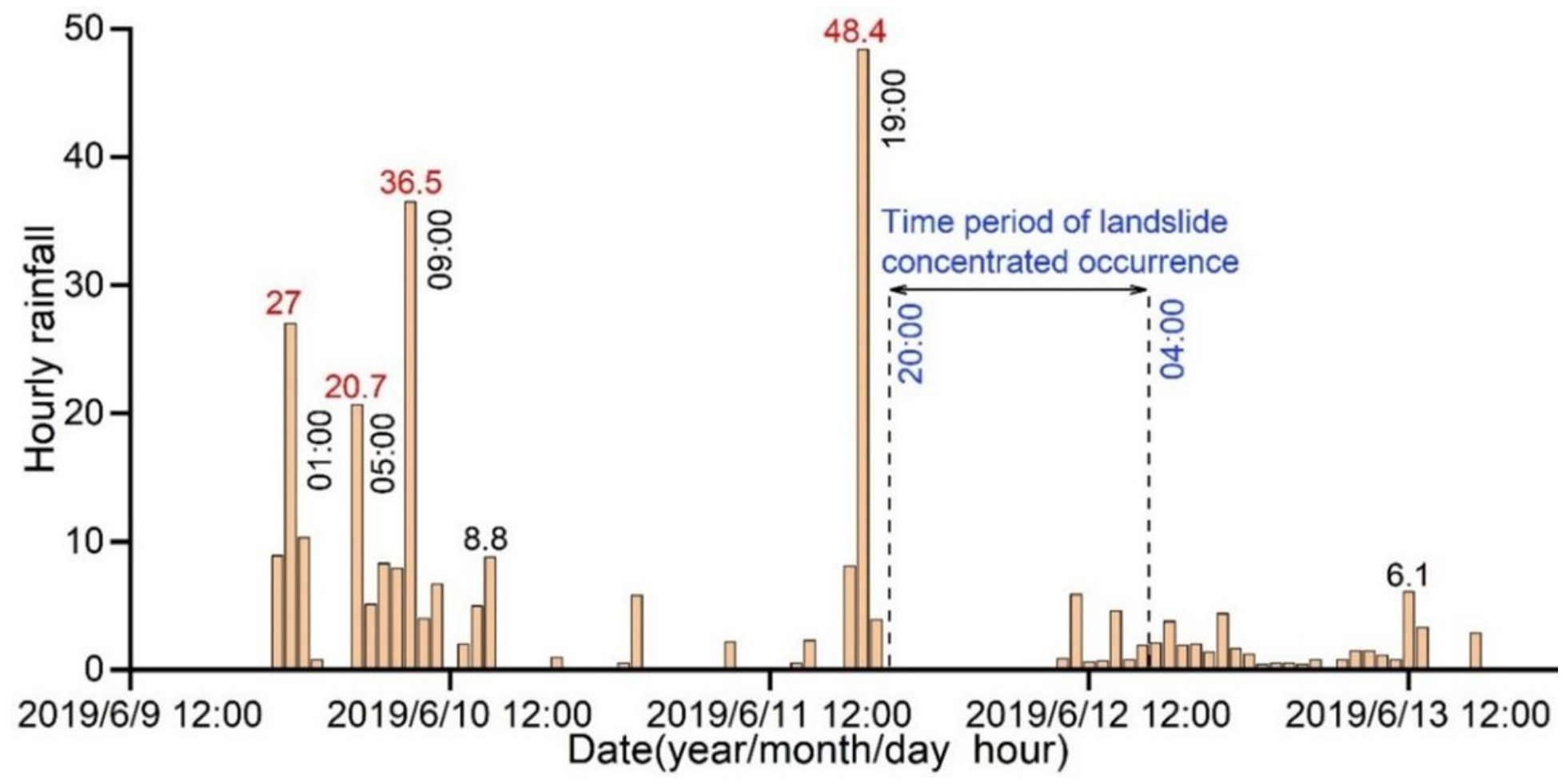

Figure 10 
Hourly rainfall distribution of Beiling town, Longchuan County from June 9th to 13, 2019
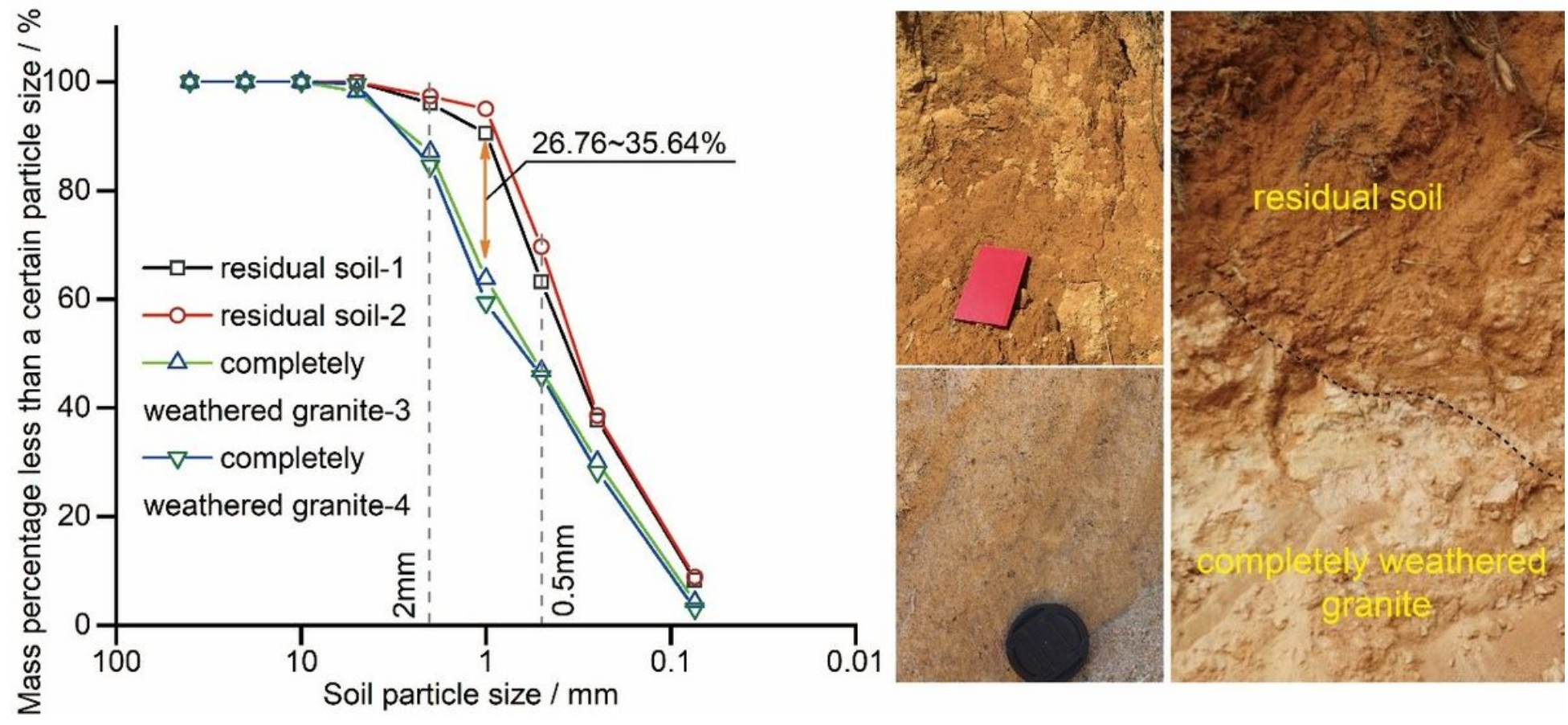

Figure 11

Gradation characteristics of residual soil and completely weathered granite 


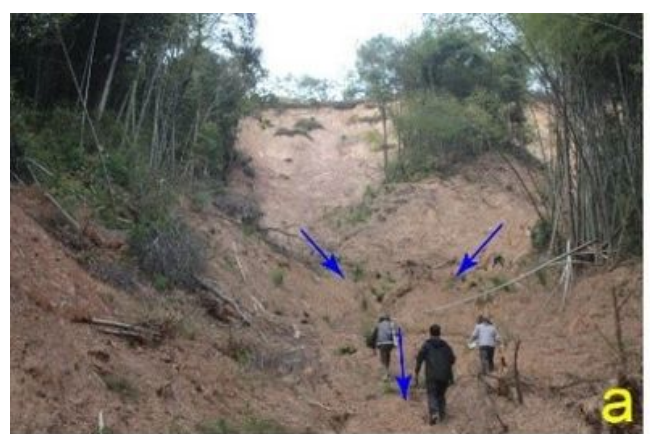

2.

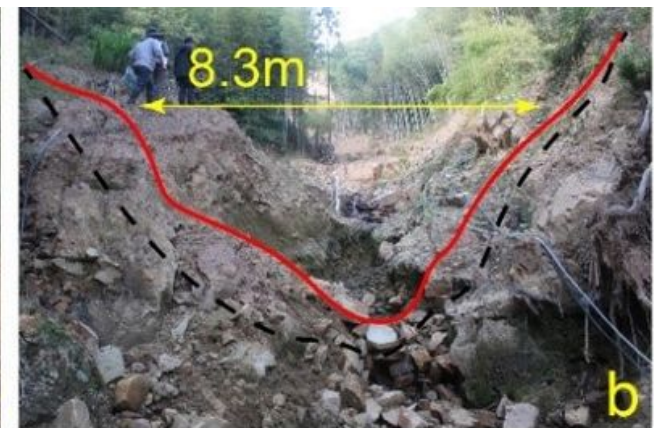

Accumulation area

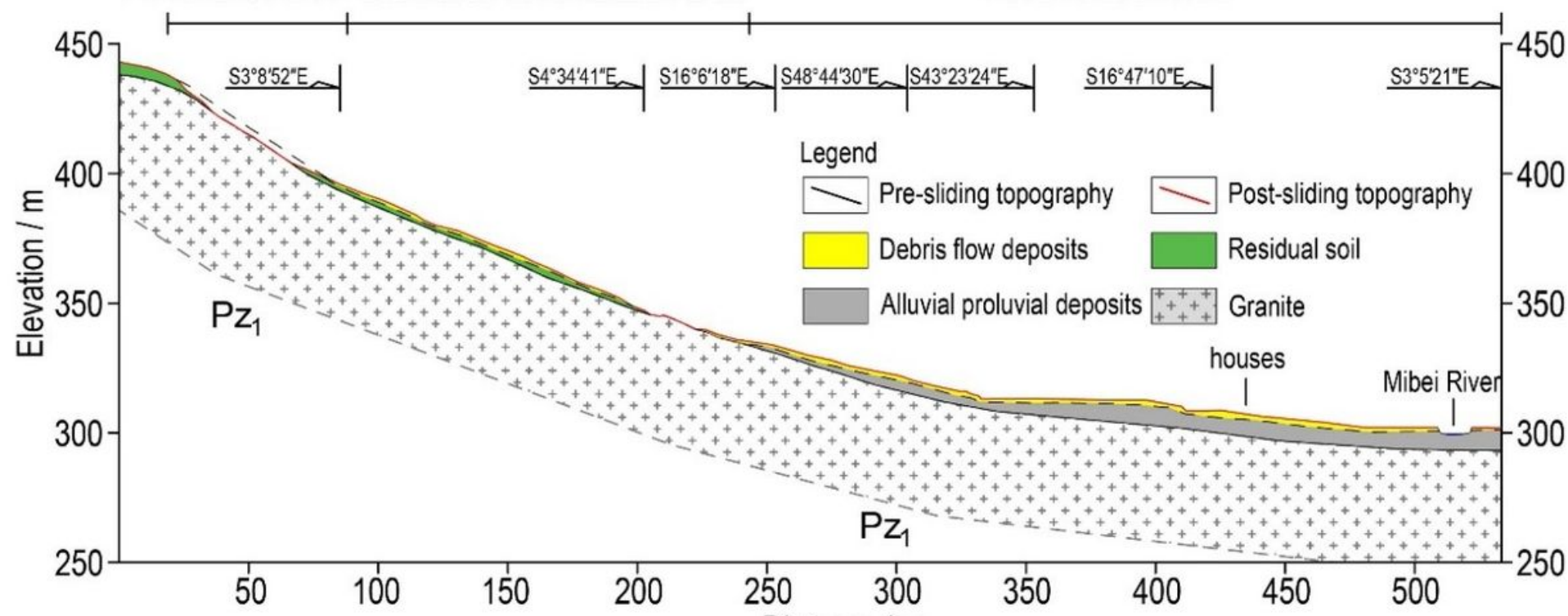

Distance / $\mathrm{m}$
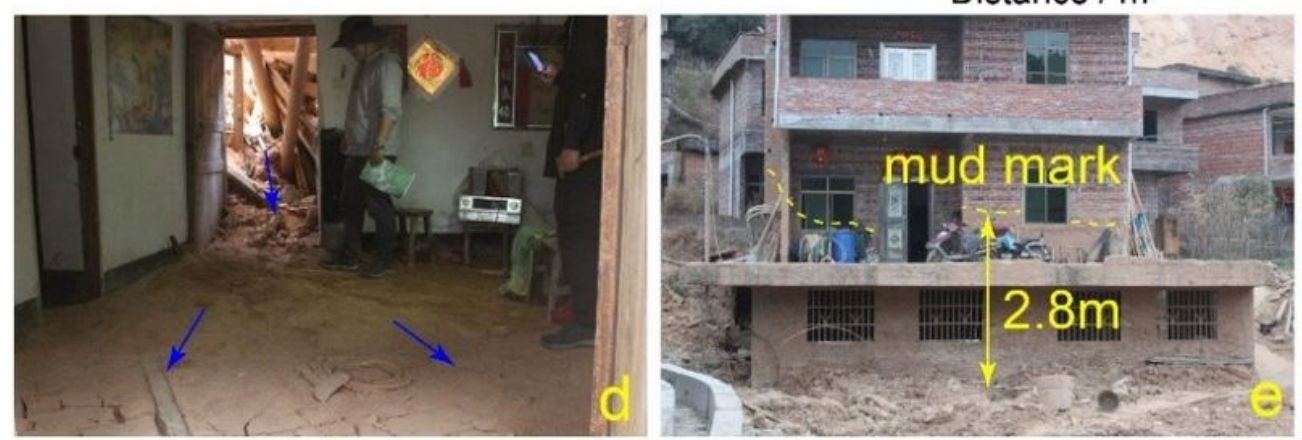

Figure 12

Characteristics of typical debris flow in the study area. (a)Characteristics of debris flow provenance area; (b)Characteristics of debris flow gully; (c)Damage of debris flow to gully slope; (d)Houses damaged by debris flow in the middle of the gully; (e)Houses affected by debris flow accumulation at gully mouth; (f)Accumulation characteristics of debris flow at gully mouth. 

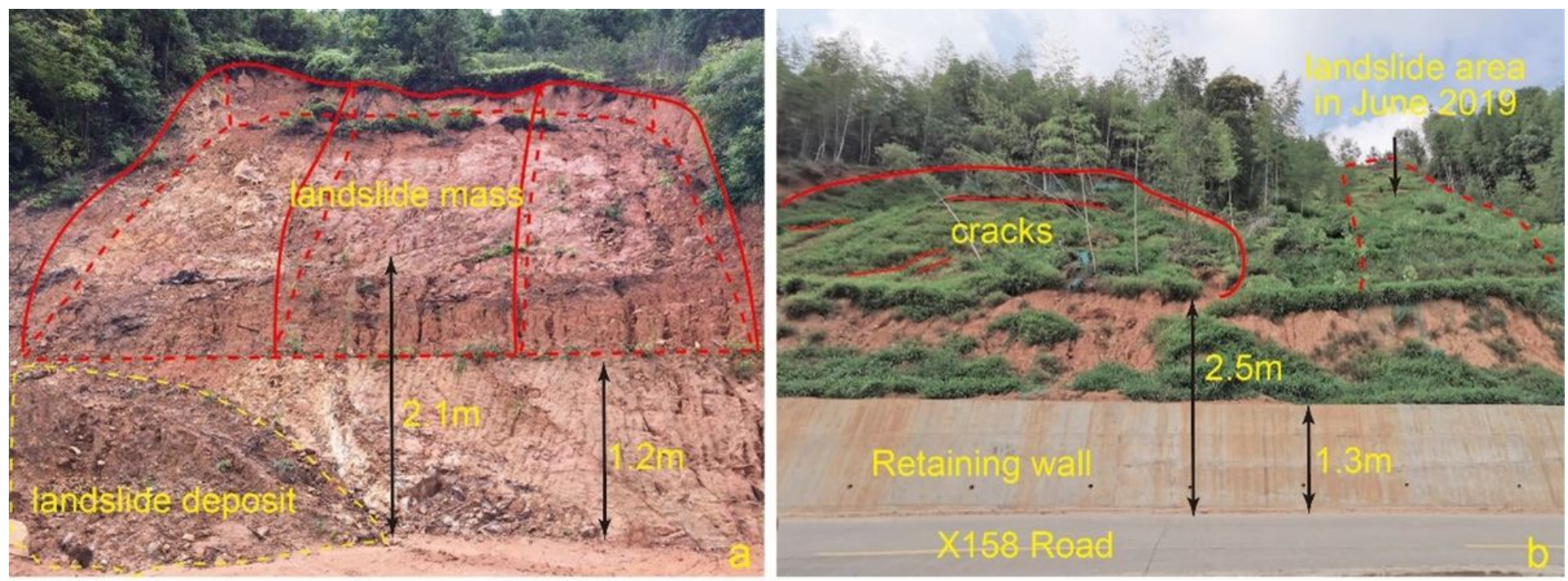

Figure 13

Characteristics of landslide hazard caused by engineering activities 